\title{
Impact of Work from Home Policy Implementation on Work Effectiveness and Productivity in Tangerang City
}

\author{
Indra Gunawan 1) \\ Indra.gunawan@ubd.ac.id
}

Agus Kusnawan 2)

Agus.kusnawan@ubd.ac.id

Eso Hernawan 3)

Eso.hernawan@ubd.ac.id

\section{1) 2) 3) Buddhi Dharma University Tangerang, Banten, Indonesia.}

\begin{abstract}
This research was conducted based on the desire of the researchers to find out how much influence the Work from Home policy has on the effectiveness and productivity of work, especially for workers in the Tangerang area

The dependent factor studied was the Work from Home policy as the independent variable (Y), while the independent factors were effectiveness $\left(X_{1}\right)$ and work productivity $\left(X_{2}\right)$. The resulting $t$ value for the work effectiveness variable is 0.647 with sig 0.519 . The results of this significance analysis are greater than 0.05 , so it means that individually the work effectiveness variable does not have an impact due to the WFH policy. The resulting t value for work productivity variable is 6.103 with sig 0.000 . The results of this significant analysis are smaller than 0.05, meaning that individually the work productivity variable has a significant impact on the implementation of WFH policies. The results obtained in this study are based on the SPSS calculation, the F count is 19.504 with F sig. 0,000 where F sig. 0.000 is smaller than 0.05, so Ho is rejected. It can be interpreted that simultaneously work effectiveness $\left(X_{1}\right)$ and work productivity $\left(X_{2}\right)$ have a significant impact on the implementation of WFH policy $(Y)$. This calculation also forms the equation $Y=9,112+0.108 X 1+0.681 X 2+e$. The $R$ square value obtained from the SPSS calculation of $0.236(23.6 \%)$ can be interpreted that work effectiveness (X1) and work productivity (X2) explain the impact of variations in the variable implementation of WFH policy (Y) by $23.6 \%$ and the rest is influenced other independent variables amounted to $76.4 \%$.
\end{abstract}

Keywords: WFH Policy, Effectiveness, Productivity. 


\section{PRELIMINARY}

At the end of 2019 the world was shocked by the discovery of a new virus called Corona. Information reported from https://www.who.int/indonesia/news/novel-coronavirus/qa-for-public Corona virus is a group of viruses that can cause disease in animals or humans. Several types of coronavirus are known to cause respiratory tract infections in humans ranging from colds to more serious coughs such as Middle East Respiratory Syndrome (MERS) and Severe Acute Respiratory Syndrome (SARS).

Effectiveness and productivity are what every leader demands in all his activities. Human resources are required to be able to work as efficiently as possible, in other words, the sacrifice is minimal but has a tremendous impact on the company. However, with the COVID 19 pandemic that has occurred in almost all parts of the world, adjustments have been made. Health protocols must be implemented in accordance with government directives, but that does not mean that productivity cannot be fulfilled. One of the health protocols that is fulfilled is the Work from Home (WFH) policy. This policy requires companies to be able to carry out their work activities from home with the help of information technology.

From the above paragraph, there is a link between the policies taken by the government and demands for work effectiveness and productivity. The WFH policy will have an impact on how effective employees are at work. In addition, the WFH policy can increase work productivity. Increasingly sophisticated technology support can support work effectiveness and productivity programs.

From the phenomena that occur above, it is interesting for the author to conduct research with the title "The Impact of Implementing Work from Home Policy on the Effectiveness and Productivity of Tangerang City Area Work".

\section{THEORETICAL BASIS}

Big Indonesian Dictionary, explain the term policy has the meaning as a series of concepts and principles that form the outline and basis of a plan in the implementation of a job, leadership, and how to act (regarding government, organization, etc.); statement of goals, objectives, principles and guidelines for management in achieving goals. Some definitions of policies according to experts can be described as follows:

(Tahir, 2014) explained that the term policy is commonly used in relation to government activities, as well as state behavior in general and these policies are contained in various forms of regulations. According to (Tahir, 2014) policy is an action that has a purpose by an actor or a number of actors to solve a problem

(Solichin Abdul Wahab, 2014) provides several policy guidelines as follows:

1. Policy must be distinguished from decisions.

2. Policy is not necessarily differentiated from administration.

3. Policy includes behavior and expectations.

4. Policies include neither action nor action.

5. Policies usually have an end result to be achieved.

6. Every policy has specific goals or objectives, either explicit or implicit.

7. Policy arises from a process that takes place over time.

8. Policies include inter-organizational and intra-organizational relationships. 
9. Public policy, although not exclusive, concerns the key roles of government institutions.

10. The policy is formulated or defined subjectively.

From some of the expert opinions above, it can be concluded that a policy is a series of actions taken in order to achieve organizational goals as outlined in the form of binding regulations and apply to certain organizations.

The word effective means successful or something that is done successfully. According to the Big Indonesian Dictionary (KBBI) Effectiveness as usability, activeness, and the existence of conformity in activities between a people carrying out a task with the expected goals.

According to (Sejathi, 2011) effectiveness is "efficiency, usefulness, supporting goals." Soewarno Handayaningrat in (Gunawan, 2003) states that: "Effectiveness is a measurement in the sense of detailing predetermined goals or objectives". (Ali Muhidin Sambas, 2009) also explains that: Effectiveness is also related to the problem of how to achieve the goals or results obtained, the use or benefits of the results obtained, the level of functional power of elements or components, and user / client satisfaction level problems.

Work productivity means, product: result, outcome develops into the word productive, which means to produce, and productivity: having the ability make or creative. The word is used in Indonesian as productivity, which means strength or ability to produce something, because it is in the organization. Productivity contains philosophical notions, work definitions and operational techniques, philosophically, productivity contains a view of life and a mental attitude that always strives to improve the quality of life. Today's condition must be better than yesterday, and tomorrow's quality of life must be better than today(Kusnawan, Agus, Andy, Eso Hernawan, Diana Silaswara, 2020). Such a view of life and mental attitude will encourage people not to feel satisfied quickly and will continue to improve their work abilities. For the definition of work, productivity is a comparison between the results achieved (output) and the total resources (input) used per unit of time, this work definition contains a method or method of measurement, although in theory it can be done but in practice it is difficult to implement, due to resources. the input used generally consists of many kinds with different proportions. (Hasibuan, 2008). The Indonesian National Productivity Council has formulated a complete definition of productivity as follows (Husein, 2014):

a. Productivity is basically a mental attitude that always has the view that the quality of life today is better than yesterday and tomorrow is better than today.

b. In general, productivity means the comparison between the results achieved (output) and the total resources used (input).

c. Productivity has two dimensions, namely effectiveness which leads to the achievement of maximum performance, namely the achievement of targets related to quality, quantity and time. The second is efficiency related to comparing inputs with their actual use or how the work is carried out.

According to L. Greenberg in (Sinungan, 1997) defines productivity as the ratio between the total expenditure at a certain time divided by the total input during that period. Productivity is also defined as the comparison of price measures for inputs and 
results, the difference between a set of total expenditures and inputs expressed in general units.

\section{RESEARCH METHODS}

According to experts, research design can be interpreted as a structured work plan in terms of the relationships between variables in a comprehensive manner so that the research results can provide answers to research questions. According to (Husein, 2014) the plan includes things that research will do, from making hypotheses and their operational implications to the final analysis.

This study uses a quantitative approach as the research design. (Creswell, 2007) states, "the quantitative approach is the measurement of objective quantitative and statistical data through scientific calculations derived from a sample of people or residents who are asked to answer a number of questions about a survey to determine the frequency and percentage of their responses". Furthermore, according to (Creswell, 2007) states that in this quantitative approach research will be pre-determined, statistical data analysis and statistical data interpretation.

This research was conducted to explain the effect of WFH policies on work effectiveness and productivity. The dependent variable $(X)$ in this study is WFH policy and the variable $(\mathrm{Y})$ consists of effectiveness (Y1) and work productivity (Y2). Based on the variables that have been described, it can be formulated in a research framework chart as follows:

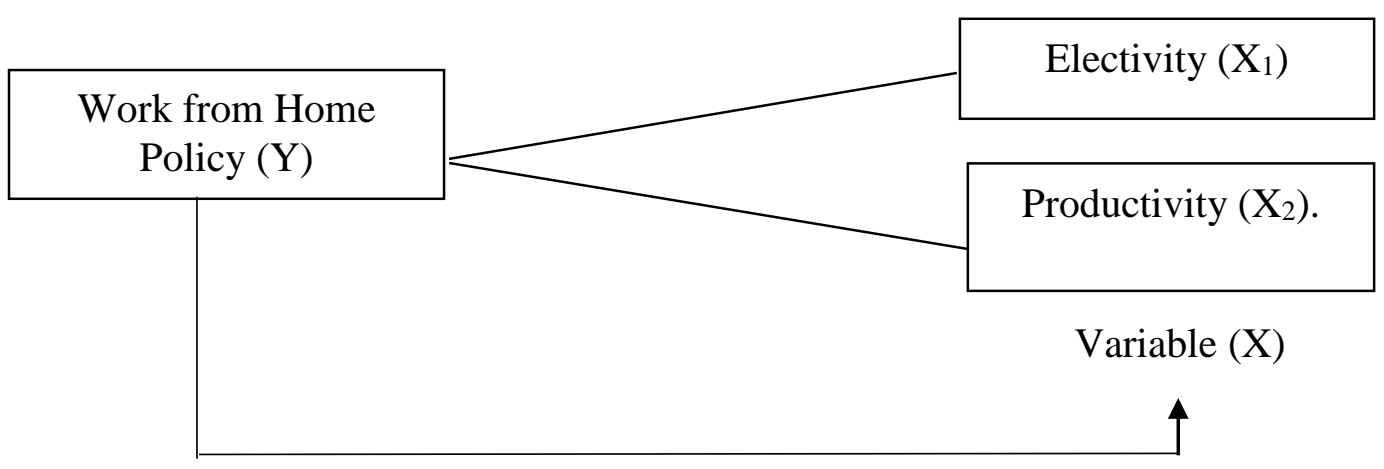

Figure 1 Framework Used

\section{RESULT AND DISCUSSION Validity Test}

The validity test is used to measure whether a questionnaire is valid or not. The questionnaire is said to be valid if the questions on the questionnaire are able to reveal something that will be measured by the questionnaire. The method used to assess the validity of the questionnaire is the product moment correlation or using Pearson's variety. The results of the $r$ table value with the number of respondents as much as 135 with a level of a $5 \%$ is 0.1411 . The conclusion from the calculation of the three variables is that all components of the variable have a value of $r$ count $>r$ table (0.1411). Thus it can be said that all the variables studied were declared valid

\section{Reliability Test}

Reliability test is a tool to measure a questionnaire which is an indicator of a variable or construct. The questionnaire is declared reliable if the respondent's answer 
to the statement is consistent or stable over time. A variable is said to be reliable if it gives a Cronbach Alpa value $>0.60$. The following are the results of the reliability test shown in Table 1 as follow:

Table 1 Reliability Test Result

\begin{tabular}{|c|c|c|c|}
\hline Variabel & Cronbach Alpa & Role Of Thumb & Information \\
\hline $\begin{array}{c}\text { Implementation WFH Policy } \\
\text { (Variabel Y) }\end{array}$ & 0,862 & 0,600 & Reliable \\
\hline Electivity (Variable $\left.\mathrm{X}_{1}\right)$ & 0,792 & 0,600 & Reliable \\
\hline Productivity (Variabel $\left.\mathrm{X}_{2}\right)$ & 0,824 & 0,600 & Reliable \\
\hline
\end{tabular}

The results of the above calculations are the results of calculations on all variables not from the statement items given to the respondent. Conclusion, of all variables are declared reliable because Cronbach's alpha value is $>0.60$.

\section{Normality Test}

The normality test is used to test whether in the regression model, confounding or residual variables have a normal distribution. The normality test method that can be used to test for residual normality is Kolmogorov-Sminov (KS). From the data normality test, the test results were 0.82 . The data will be considered normal if the Asymp.Sig value $>0.05$, so it can be concluded that all data from the questionnaire have been normally distributed.

\section{Multicolineritis Test}

The multicollinearity test aims to test whether the regression model found a correlation between the independent variables. A good regression model should not have a correlation between the independent variables. To determine the multicollinearity in the regression model, it can be seen from the Variance Inflation Factor (VIF) value. The condition for the multi-collinearity test is if the Tolerance value is $>0.10$ or the VIF value is $<10.00$. The conclusion from the test results can be stated that all research data variables do not occur multicollinearity. This happens because the Tolerance value $(0.988)>0.10$ and the VIF value $(1.0120)<10.00$.

\section{Heteroscedasticity Test}

The heterosdecasticity test aims to test whether in the regression model there is an inequality of variants from the residuals or other observations. In this study, the way to determine whether or not heteroscedasticity is in the regression model is using the Glejser test. A study said that heteroscedasticity did not occur if the sig value was $>0.05$.

The results of the heteroscedasticity test showed that the effectiveness variable was 0.133 and the productivity variable was 0.988 . Conclusion, from all variables it is stated that heteroscedasticity does not occur because all the variables studied show a $\operatorname{sig}>0.05$.

\section{Multiple Regression Test}

The method used in testing the hypothesis in this study is multiple regression analysis. This analysis is used to measure the strength of the relationship between the 
independent variable and the dependent variable, and to show the direction of the relationship between these variables. This analysis will form an equation. The result of multiple regression test shows the constant result of 9,112 effectiveness variable 0,108 productivity variable 0,681

The regression equation that can be generated from the calculation of multiple regression tests is as follows:

$$
\mathrm{Y}=9,112+0,108 \mathrm{X} 1+0,681 \mathrm{X}_{2}+\mathrm{e}
$$

From the above equation, it can be used as a reference to interpret as follows:

- The constant coefficient is positive, meaning that the WFH policy will still have an impact on effectiveness and productivity variable even though it is not taken into account. The positive coefficient of effectiveness variable means that WFH policies will have an influence on effectiveness variable.

- Productivity coefficient is positive, meaning that WFH policy will continue to increase productivity variable.

\section{Hypothesis Test}

This test is done to prove the hypothesis based on existing research. This test includes the $t$ test, the $F$ test and the coefficient of determination. The results of the research hypothesis test can be described as follows:

Model Summary

\begin{tabular}{|c|c|c|c|c|}
\hline Model & $\mathrm{R}$ & R Square & $\begin{array}{c}\text { Adjusted R } \\
\text { Square }\end{array}$ & $\begin{array}{l}\text { Std. Error of the } \\
\text { Estimate }\end{array}$ \\
\hline 1 & $.486^{a}$ & .236 & .224 & 6.679 \\
\hline
\end{tabular}

\begin{tabular}{|c|c|c|c|c|c|}
\hline \multicolumn{6}{|c|}{ ANOVA $^{a}$} \\
\hline Model & Sum of Squares & $\mathrm{df}$ & Mean Square & $\mathrm{F}$ & Sig. \\
\hline Regression & 1740.121 & 2 & 870.060 & 19.504 & $.000^{\mathrm{b}}$ \\
\hline 1 Residual & 5620.872 & 126 & 44.610 & & \\
\hline Total & 7360.992 & 128 & & & \\
\hline
\end{tabular}

a. Dependent Variable: Total_Y_Implementasi_WFH

b. Predictors: (Constant), Total_X2_Produktivitas_Kerja, Total_X1_Efektivitas_Kerja

Coefficients $^{\mathrm{a}}$

\begin{tabular}{|c|c|c|c|c|c|c|}
\hline \multirow{2}{*}{\multicolumn{2}{|c|}{ Model }} & \multicolumn{2}{|c|}{ Unstandardized Coefficients } & Standardized & \multirow[t]{2}{*}{$\mathrm{t}$} & \multirow[t]{2}{*}{ Sig. } \\
\hline & & $B$ & Std. Error & Beta & & \\
\hline \multirow{3}{*}{1} & (Constant) & 20.974 & 9.112 & & 2.302 & .023 \\
\hline & $\begin{array}{c}\text { Total_X1_Efektivitas } \\
\text { Kerja }\end{array}$ & .108 & .167 & .051 & .647 & .519 \\
\hline & $\begin{array}{l}\text { Total_X2_Produktivit } \\
\text { as Keria }\end{array}$ & .681 & .112 & .478 & 6.103 & .000 \\
\hline
\end{tabular}

a. Dependent Variable: Total_Y_Implementasi_WFH

\section{T Test}

The purpose of this test is to determine the effect of individual independent variables in explaining variations in the dependent variable. To provide an interpretation of the $t$ test, it can be explained in the results of the SPSS calculation. Before interpreting the value generated by SPSS, it is necessary to determine the $t$ table 
in this study. The value of $\mathrm{t}$ table with 129 respondents and 3 research variables was obtained at 1.97912

The resulting $t$ value for the effectiveness variable is 0.647 with sig 0.519 . The results of this significance analysis are greater than 0.05 , so it means that individually the effectiveness variable does not have an impact due to the WFH policy.

The resulting $\mathrm{t}$ value for the work productivity variable is 6,103 with sig 0,000 . The results of this significant analysis are smaller than 0.05 , meaning that individually the productivity variable has a significant impact on the implementation of WFH policies.

\section{F Test}

This test aims to determine the extent to which the independent variables used are able to explain the dependent variable. In this study, the variable effectiveness $\left(X_{1}\right)$, productivity $\left(\mathrm{X}_{2}\right)$, is simultaneously related to the dependent variable, namely the implementation of WFH (Y) policies, and whether the model is appropriate or not. Before interpreting the value generated by SPSS, it is necessary to determine the $f$ table value in this study. The value of $\mathrm{f}$ table with 129 respondents and 3 research variables is obtained at 2.68;

The results obtained in this study based on SPSS calculations obtained the value of $F$ count 19.504 with $F$ sig. 0,000 where $F$ sig. 0.000 is smaller than 0.05 , so Ho is rejected. It can be interpreted that simultaneously effectiveness $\left(\mathrm{X}_{1}\right)$ and productivity $\left(\mathrm{X}_{2}\right)$ have a significant impact on the implementation of WFH policy $(\mathrm{Y})$.

\section{Coefficient of Determination $\left(\mathbf{R}^{2}\right)$}

The coefficient of determination $\left(\mathrm{R}^{2}\right)$ is used to measure the model's ability to explain the variation in the dependent variable. The value of $\left(R^{2}\right)$ is between 0 and 1 . A small value of $\left(\mathrm{R}^{2}\right)$ means that the ability of the independent variables to explain the variation in the dependent variable is very limited. The $\mathrm{R}$ square value obtained from the SPSS calculation of $0.236(23.6 \%)$ can be interpreted that effectiveness $\left(\mathrm{X}_{1}\right)$ Variable and productivity $\left(\mathrm{X}_{2}\right)$ variable explain the impact of variations in the variable implementation of WFH policy $(Y)$ by $23.6 \%$ and the rest is influenced other independent variables amounted to $76.4 \%$.

\section{DISSCUSSION}

The results of the analysis in this study indicate that the effectiveness variable has no impact due to the implementation of WFH policies. This illustrates that the effectiveness of work can be done with or without the implementation of WFH policies. With increasingly fierce global competition, companies are required to be able to work more effectively in order to win the competition. Thus the implementation of the WFH policy is felt to have no significant impact on work effectiveness.

The results of the analysis in research of productivity variables show a positive impact due to the implementation of WFH policies. This shows that employees are increasingly productive with the implementation of WFH policies. Availability of internet access and time for family makes employees more productive at work. They are not constrained by traffic jams, wasted lunch time, gathering time so that workers can focus more on completing their work. 
As simultaneously effectiveness and productivity variable have a significant impact due to the implementation of WFH policies. This indicates that the implementation of WFH will have an impact on work effectiveness and productivity. This is because a lot of time can be used efficiently to work without being wasted due to travel time, maintained health conditions and so on.

\section{CONCLUTION}

Based on the results of the analysis and discussion of data in the previous chapter, the authors obtained several conclusions that can be drawn from the research regarding the impact of implementing WFH policies on work effectiveness and productivity in the Tangerang area as follows:

- The results of this study indicate that $23.6 \%$ of the variation in the dependent variable on the implementation of WFH policies has an impact on the independent variables, namely work effectiveness and productivity. While the remaining $76.4 \%$ is influenced by other factors.

- The effectiveness variable has no impact due to the implementation of WFH policies. This means that work effectiveness will still be fulfilled even without the implementation of WFH policies.

- Productivity variables indicate a positive impact due to the implementation of WFH policies. This means that working at home will save time and optimize employee work time.

\section{REFERENCE}

Abdul Wahab, Solichin. 2014. Analisis Kebijaksanaan dari Formulasi ke Implementasi Kebijaksanaan Negara. Jakarta: Bumi Aksara.

Arifin Tahir, 2014, Kebijakan Publik dan Transparansi Penyelenggaraan Pemerintahan Daerah. Bandung: Alvabeta

Ali Muhidin Sambas. (2009). Konsep Efektivitas Pembelajaran,. Pustaka Setia,Bandung. Creswell, J. W. (2007). Research Design: Qualitative, Quantitative and Mixed Method Aproaches. SAGE Publications. https://doi.org/10.4135/9781849208956

Gunawan, A. (2003). Analisis Consumer Decision Model Untuk Pengukuran Efektifitas Periklanan. Jurnal Ilmiah "Manajemen $\mathcal{E}$ Bisnis."

Hasibuan, M. S. P. (2008). Organisasi \& Motivasi. Dasar Peningkatan Produktivitas. In Pagar Alam.

Husein, U. (2014). Riset Sumber Daya Manusia Dalam Organisasi. In Jurnal Riset Akuntansi Dan Bisnis.

Kusnawan, Agus, Andy, Eso Hernawan, Diana Silaswara, T. S. (2020). The Effect of Digital Payment to Millennial Consumer Purchase Decision. TEST Engineering $\mathcal{E}$ Management Magazine, 82(25 January 2020), 5116-5129. http://testmagzine.biz/index.php/testmagzine/article/view/1651/1491

KBBI, 2020. Kamus Besar Bahasa Indonesia (KBBI). [Online] Available at: https://kbbi.web.id/bijak

Sejathi. (2011). EFEKTIVITAS PEMANFAATAN JEJARING SOSIAL (FACEBOOK) SEBAGAI MEDIA BISNIS ONLINE DALAM MENINGKATKAN VOLUME PENJUALAN (Studi Kasus Makassar Dagang). Journal of Chemical Information and 
Modeling.

Sinungan, M. (1997). PRODUKTIVITAS APA DAN BAGAIMANA. In Jakarta:Bumi Raksa.

Solichin Abdul Wahab. (2014). Analisis kebijaksanaan : Dari formulasi ke implementasi kebijaksanaan negara. In Analisis kebijaksanaan: Dari formulasi ke implementasi kebijaksanaan negara.

Tahir, A. (2014). Kebijakan Publik \& Transparansi Penyelenggaran Pemerintah Daerah. Bandung. Alfabeta,.

Umar, Husein. 2002, Evaluasi Kinerja Perusahaan. Jakarta: PT Gramedia Pustaka Utama.

Umar, Husein. 2004. Metode Riset Ilmu Administrasi. Penerbit PT Gramedia Pustaka Utama: Jakarta.

https://jdih.setkab.go.id/PUUdoc/176085/PP_Nomor_21_Tahun_2020.pdf https://www.who.int/indonesia/news/novel-coronavirus/qa-for-public 